\title{
Deadly intracranial bleed in patients with dengue fever: A series of nine patients and review of literature
}

\author{
Sam Jo Ee, Gee Teak Sheng, Nasser Abdul Wahab \\ Department of Neurosurgery, Hospital Pulau Pinang, Jalan Residensi, 10990 Penang, Malaysia
}

\section{ABSTRACT}

Introduction: Dengue fever is a global pandemic threat with increasing incidence. To date, there are no cures and the effectiveness of dengue vaccines is still uncertain. World Heath Organization introduced expanded dengue syndrome to include unusual presentations of dengue fever including severe neurologic complications. One of the deadly complications is intracranial hemorrhage (ICH). Methodology: We collected data of patients with ICH diagnosed via a plain computed tomography of the brain (CT brain) with thrombocytopenia and positive Dengue virus type 1 nonstructural protein ( $\mathrm{NS}_{1}$ ) antigen test or positive dengue serology IgM from January 2014 till June 2015 at our center. Nine patients were included and all 20 other remaining patients reported in literature so far are discussed. Discussion: We found that all patients in our center requiring neurosurgical intervention died. Another interesting observation is that detection of Dengue IgG usually meant more severe ICH and poorer outcomes. From our series, platelet levels did not seem to influence the outcome. Conclusion: We recommend that for early detection of ICH, Dengue IgG should be routinely screened and a high index of suspicion be maintained. Future research should be focused on determining predictors of ICH in patients with dengue fever so that preventive steps can be taken as mortality is high and no treatment seems beneficial at the moment once severe ICH occurs.

Key words: Craniectomy, dengue encephalopathy, dengue fever, dengue hemorrhagic fever, intracranial bleed, intracranial hemorrhage

\section{Introduction}

Dengue fever is the most significant arbovirus infection in Malaysia and tropical countries, with an upward trend from 44.3 cases/100,000 population in 1999 reaching 181 cases/100,000 population in 2007. ${ }^{[1]}$ The World Health Organization (WHO) ranks dengue as the most crucial mosquito-borne viral disease in the world. This infectious disease affects more than 100 endemic countries including regions of Asia, Americas, Africa, and Eastern Mediterranean, many of which are rural and developing nations, causing about 50-100 million new dengue infections occurring each year. The dengue virus is a global pandemic threat which has

\section{Address for correspondence:}

Dr. Jo Ee Sam, Department of Neurosurgery, Hospital Pulau Pinang, Jalan Residensi, 10990 Penang, Malaysia.

E-mail: joeesam@gmail.com

\begin{tabular}{|l|l|}
\hline \multicolumn{2}{|c|}{ Access this article online } \\
\hline Quick Response Code: & Website: \\
\hline & www.ruralneuropractice.com \\
\cline { 2 - 3 } & \\
\hline
\end{tabular}

increased incidence of 30 -fold in the past five decades, with multiple new outbreaks. ${ }^{[2]}$ Although the reported number of patients having intracranial hemorrhage (ICH) caused by dengue virus is rare and only 20 cases excluding those in our series have been reported so far, it is likely that its incidence is under-reported or under-diagnosed with the current global disease burden. There were 5866 reported dengue cases and 17 dengue-related deaths in Penang, Malaysia, from January 2014 till June 2015. At least five deaths were associated with $\mathrm{ICH} \cdot{ }^{[3]}$ The dengue virus, a member of the flavivirus group in the family Flaviviridae, is a single-stranded enveloped RNA virus, of which there are four known serotypes, namely DENV 1-4. Its main vectors are the Aedes aegypti and Aedes albopictus mosquitoes. Dengue infection understanding has improved tremendously, but still no cure has been devised and the best strategy so far to curb the disease is through prevention and

This is an open access article distributed under the terms of the Creative Commons Attribution-NonCommercial-ShareAlike 3.0 License, which allows others to remix, tweak, and build upon the work non-commercially, as long as the author is credited and the new creations are licensed under the identical terms.

For reprints contact: reprints@medknow.com

How to cite this article: Sam JE, Gee TS, Nasser AW. Deadly intracranial bleed in patients with dengue fever: A series of nine patients and review of literature. J Neurosci Rural Pract 2016;7:423-34. 
control of its mosquito vectors. Dengue vaccines have been created but most are still undergoing the clinical development stage, and only Mexico and Philippines have approved its use so far. ${ }^{[4]}$ With better understanding of the disease, $\mathrm{WHO}$ has proposed new classification schemes. ${ }^{[5-7]}$ The term "expanded dengue syndrome" was introduced to include unusual presentations of dengue fever with severe organ involvement including severe neurologic complications. ${ }^{[7]}$ The incidence of dengue encephalopathy ranges from $0.5 \%$ to $6.2 \% .^{[8-10]}$ Out of the 5400 patients with dengue fever reported by Cam et al., only one had an ICH. ${ }^{[8]}$ The mechanism of which patients with dengue infection may be more prone to ICH is complex, but the main contributors are coagulopathy, platelet dysfunction, thrombocytopenia, and vasculopathy. ${ }^{[8,11]}$ Unfortunately, dengue fever with ICH has high morbidity and fatality, but little is known about it.

\section{Methods}

We collected data of all patients with $\mathrm{ICH}$ diagnosed via a plain computed tomography $(\mathrm{CT})$ of the brain with positive dengue virus Type 1 nonstructural protein (NS1) antigen test or positive dengue serology IgM with thrombocytopenia from January 2014 till June 2015 at our center. A total of nine patients (Patient A to Patient I) were analyzed at our center. The data included were basic demographic data, existing comorbid, presenting symptoms, other dengue-related complications, the day ICH was diagnosed in relation to onset of fever, Glasgow coma scale (GCS), and pupils size and light response on presentation, platelet counts during diagnosis of $\mathrm{ICH}$, lowest platelet counts recorded, international normalized ratio (INR), activated partial thromboplastin time (APTT), dengue IgM and IgG seropositivity, type of $\mathrm{ICH}$, volume of $\mathrm{ICH}$, presence of midline shift and patency of basal cisterns, surgical intervention, and outcome.

Outcome was assessed using the GCS. ${ }^{[12]}$ The volumes of intracerebral hematomas were calculated using the well-accepted ABC/2 "ellipsoid method." ${ }^{[13-15]}$ In cases where there is a subdural hemorrhage, the maximum thickness of the hemorrhage was measured. We defined an intracranial lesion needing surgery as: (1) any intracranial lesion causing a midline shift of $5 \mathrm{~mm}$ or more, and/or, (2) effacement of basal cisterns on CT brain.

There are three methods of laboratory detection in our center, namely, Panbio dengue IgM Capture ELISA (sensitivity of $94.7 \%$ for primary infections, $55.7 \%$ for secondary infections and specificity of $100 \%$ ), Diaxis ${ }^{\mathrm{TM}}$ dengue NS1 Antigen test (sensitivity of $97.9 \%$ and specificity of 99\%), and Acco dengue IgG/IgM-NS1 Combo rapid detection kit (IgG/IgM: Sensitivity 90\% and specificity $100 \%$, NS1: Sensitivity $96 \%$ and specificity $100 \%)$.

\section{Ethics Committee Approval}

We have attained approval from the Medical Research and Ethics Committee of Malaysia.

\section{Search Strategy and Selection Criteria}

For our literature review, we performed a PubMed and Google Scholar search using the keywords "dengue," "intracranial hemorrhage," and "intracranial bleed" without specifying a time interval. The same data as our series were collected and tabulated wherever possible. Reports where diagnosis of dengue infection is questionable or very limited information of the case is explained were excluded from the study. A total of twenty patients from other case reports and series were analyzed.

\section{Results}

Our findings are summarized in Tables 1 and 2. Fever and vomiting were seen in all patients, and surprisingly, only $55 \%$ of them had a history of headache at presentation. This of course may be due to the low GCS of patients where history from family members may not be accurate. Sixty-seven percent of the patients had altered or reduced conscious level. The mean age was 59.3 years (range 43-86 years old) and seven of the patients were males. The day of detection of ICH from fever onset ranged from 4 to 22 days. The ICH of Patient I was most likely detected late as the CT of the brain was done only after the patient had poor GCS recovery when sedation was stopped. Five patients had hypertension, and two patients had diabetes mellitus. Four of the patients had other bleeding tendencies and three of the patients were in clinical shock at the time of diagnosis of ICH. Both patients who had hematemesis died. The mean platelet count, INR, and APTT were $31 \times 10^{9} / \mathrm{L}$ (range 2-80 × 10\%/L), 1.2 (range 0.9-2.3), and 37.3 (range 27.7 - more than 180), respectively. The lowest platelet count was the platelet level at diagnosis for three of the patients but was even lower for six of the patients. Seven patients had raised alanine transaminase (ALT) levels (range 30-784 U/L). Out of the nine patients, eight had positive NS1 test, two had positive IgM test, and three had positive $\operatorname{IgG}$ test. It is interesting that three of the 
patients with positive IgG had ICH requiring surgery and all of them died whereas two patients with negative IgG did not have ICH requiring surgery and survived. It is unfortunate that IgG was not done for all patients. Four patients had cerebral convexity subdural hemorrhage, two patients had intracerebral hemorrhage, two patients had subarachnoid hemorrhage, and two had tentorium cerebelli subdural hemorrhage.

All patients with intracranial lesions requiring surgery had GCS of eight or less and died. The other 4 patients had GCS of 14 or 15 and was discharged from the hospital, albeit one patient with a Glasgow outcome scale (GOS) of 3. Five patients had surgical lesions, but only two patients underwent craniectomy. The other three patients were poor surgical candidates in terms of hemodynamic instability or persistent low platelet counts below $100 \times 10^{9} /$ L despite multiple units of platelet transfusions. Patient B's platelet levels remained low with the highest platelet level of $46 \times 10^{9} / \mathrm{L}$ during admission and the patient required 4 types of inotropic support for shock [Figure 1]. Patient F underwent cardiopulmonary resuscitation on presentation for cardiac arrest and required 2 types of inotropes. Patient $G$ required 3 inotropes and the highest recorded platelet count was $68 \times 10^{9} / \mathrm{L}$ [Figure 2]. Patient A received platelet and fresh frozen plasma (FFP) transfusion till platelet level reached $101 \times 10^{9} / \mathrm{L}$, INR $1 \cdot 2$, and APTT 33.8. The patient then underwent a right decompressive craniectomy, evacuation of subdural hemorrhage, and external ventricular drainage catheter insertion for intracranial pressure monitoring $8 \mathrm{~h}$ after admission [Figure 3]. Patient $C$ also received multiple units of platelet transfusion till platelet levels reached $109 \times 10^{9} / \mathrm{L}$. The patient then underwent a parietal craniectomy $8 \mathrm{~h}$ after admission, but excessive bleeding complicated the procedure and the attempt to evacuate the entire clot was abandoned [Figure 4]. Both patients who underwent surgery were nursed in the Intensive Care Unit with cerebral resuscitation care. Unfortunately, both patients deteriorated soon after the operation and died.

\section{Results of Other Case Reports and Series}

The presenting complaints in other reports are summarized in Table 1 as well. ${ }^{[16-27]}$ Overall, fever, reduced or altered consciousness, vomiting, and headache are the top complaints. Three of the patients had shock of which two died. Platelet counts on diagnosis ranged from 15 to $100 \times 10^{9} / \mathrm{L}$. As in our series, it is seen again that patients with lower platelet levels did not necessarily have worse outcomes and that higher platelet levels did not seem to protect patients from fatal ICH. Nine of the reported patients had elevated ALT levels. Dengue IgG was detected in two patients where one died and another had outcome of GOS of 3 or 4 . Intraparenchymal hemorrhage was seen in 13 patients, pontine hemorrhage in two patients, intraventricular hemorrhage in two patients, medullary hemorrhage in one patient, cerebellar hemorrhage in one patient, and subdural hemorrhage in four patients. All the case reports did not state the volume or thickness of the bleeds, or whether the basal cisterns were effaced or patent. Midline shift was detected in six patients, but the extent of the shift was not specified to determine if surgery was required. It is highly possible these six patients required surgery by reviewing the pictures that were included in the reports. Three patients underwent neurosurgical intervention and survived. Our series has dissimilar findings where all patients requiring surgery died soon after admission. Out of 20 patients, 11 died, six had GOS of $2-4$, and three had GOS of 5 [Table 3].

Table 1: Presenting symptoms of the patients

\begin{tabular}{|c|c|c|c|c|c|c|}
\hline Symptoms & $\begin{array}{l}\text { Number of } \\
\text { patients in } \\
\text { our center }\end{array}$ & $\begin{array}{l}\text { Percentage } \\
\text { of patients } \\
\text { in our center }\end{array}$ & $\begin{array}{l}\text { Number of } \\
\text { patients in other } \\
\text { reports and series }\end{array}$ & $\begin{array}{l}\text { Percentage of } \\
\text { patients in other } \\
\text { reports and series }\end{array}$ & $\begin{array}{l}\text { Total number of } \\
\text { patients including other } \\
\text { reports and series }\end{array}$ & $\begin{array}{c}\text { Percentage of } \\
\text { total number } \\
\text { of patients } \\
\end{array}$ \\
\hline Fever & 9 & 100 & 20 & 100 & 29 & 100 \\
\hline Vomiting & 9 & 100 & 11 & 55 & 20 & 68 \\
\hline $\begin{array}{l}\text { Reduced/altered } \\
\text { consciousness }\end{array}$ & 6 & 67 & 11 & 55 & 17 & 58 \\
\hline Headache & 5 & 55 & 10 & 50 & 15 & 52 \\
\hline $\begin{array}{l}\text { Other bleeding } \\
\text { tendencies }\end{array}$ & 4 & 44 & 3 & 15 & 7 & 24 \\
\hline Seizures & 1 & 11 & 5 & 25 & 6 & 21 \\
\hline $\begin{array}{l}\text { Focal neurological } \\
\text { deficit }\end{array}$ & 0 & 0 & 8 & 40 & 8 & 28 \\
\hline Rash & 1 & 11 & 6 & 30 & 4 & 14 \\
\hline Diarrhea & 3 & 33 & 1 & 5 & 2 & 7 \\
\hline Abdominal pain & 0 & 0 & 1 & 5 & 1 & 3 \\
\hline
\end{tabular}




\section{Discussion}

Laboratory challenges in the early diagnosis of dengue infection and significance of early IgG dengue antibody detection in relation to intracranial bleeds

There are no specific symptoms that clearly differentiate dengue fever from other common febrile infectious diseases such as chikungunya, leptospirosis, malaria, and influenza. While chikungunya infection may be distinguished from dengue fever, as chikungunya may cause significant postillness arthralgia and potentially debilitating polyarthralgia, objective assessment lies

Table 2: Characteristics of patients from our center

\begin{tabular}{|c|c|c|c|c|c|c|c|c|c|}
\hline Characteristics & A & B & C & D & E & $\mathbf{F}$ & $\mathbf{G}$ & $\mathbf{H}$ & I \\
\hline Age & 47 & 43 & 54 & 59 & 86 & 66 & 62 & 69 & 48 \\
\hline Gender & Male & Male & Male & Female & Male & Male & Male & Male & Female \\
\hline Comorbids & - & $\mathrm{DM} / \mathrm{HPT}$ & - & - & DM/HPT & НPT & - & НPТ & HPT \\
\hline $\begin{array}{l}\text { Presence of shock } \\
\text { during diagnosis } \\
\text { of ICH }\end{array}$ & No & Yes & No & No & No & Yes & Yes & No & No \\
\hline $\begin{array}{l}\text { Other dengue } \\
\text { complications }\end{array}$ & No & $\begin{array}{l}\text { Pleural } \\
\text { effusion, } \\
\text { UGIB, } \\
\text { myocarditis, } \\
\text { hepatitis }\end{array}$ & No & $\begin{array}{l}\text { Gum } \\
\text { bleeding }\end{array}$ & $\begin{array}{l}\text { Gum } \\
\text { bleeding, } \\
\text { hepatitis }\end{array}$ & No & UGIB & No & $\begin{array}{l}\text { Ascites, } \\
\text { pleural } \\
\text { effusion }\end{array}$ \\
\hline $\begin{array}{l}\text { Day of detection of } \\
\text { ich from fever onset }\end{array}$ & 7 & 6 & 7 & 9 & 5 & 5 & 6 & 4 & 22 \\
\hline $\begin{array}{l}\text { Platelet when ICH } \\
\text { diagnosed (x10 } / \mathrm{L})\end{array}$ & 31 & 2 & 24 & 3 & 80 & 66 & 14 & 21 & 36 \\
\hline $\begin{array}{l}\text { Hematocrit on } \\
\text { presentation (\%) }\end{array}$ & 42.7 & 41.7 & 43.1 & 24.8 & 33 & 39.4 & 34.1 & 32.4 & 43 \\
\hline INR on presentation & 2.3 & 1.2 & 1 & 1.1 & 0.9 & 1 & 1 & 1 & 1.2 \\
\hline $\begin{array}{l}\text { APTT on } \\
\text { presentation }\end{array}$ & $\begin{array}{l}>180 \text { (out of } \\
\text { detectable } \\
\text { range) }\end{array}$ & 45.4 & 35 & 27.7 & 34.6 & 37.2 & 38.4 & 39.8 & 40.5 \\
\hline $\begin{array}{l}\text { Lowest platelet } \\
\left(x 10^{9} / \mathrm{L}\right)\end{array}$ & 31 & 2 & 15 & 3 & 74 & 66 & 8 & 17 & 4 \\
\hline Albumin (g/L) & 40.7 & 13 & 15 & 27 & 30 & 27 & 32 & 28 & 26 \\
\hline $\mathrm{ALT}(\mathrm{U} / \mathrm{L})$ & 65 & 146 & 44 & 70 & 107 & 31 & 53 & 30 & 784 \\
\hline NS1 antigen & Positive & Negative & Positive & Positive & Positive & Positive & Positive & Positive & Positive \\
\hline Dengue IGM & Negative & Positive & Positive & Negative & Negative & Not done & Negative & Negative & Negative \\
\hline Dengue IGG & Positive & Postive & Not done & Negative & Negative & Not done & Positive & Not done & Negative \\
\hline GCS & E1V1M3 & $\begin{array}{l}\text { Patient was } \\
\text { intubated and } \\
\text { sedated for } \\
\text { respiratory } \\
\text { failure }\end{array}$ & E1V1M3 & E4V5M6 & E4V4M6 & E1V1M1 & E1V1M3 & E4V5M6 & $\begin{array}{l}\text { Patient was } \\
\text { intubated and } \\
\text { sedated for } \\
\text { respiratory } \\
\text { failure }\end{array}$ \\
\hline Pupils & Anisocoria 3/2 & Anisocoria 4/2 & $\begin{array}{l}\text { Fixed } \\
\text { dilated 5/5 }\end{array}$ & $\begin{array}{l}\text { Equal } \\
\text { reactive } \\
3 / 3\end{array}$ & $\begin{array}{l}\text { Equal } \\
\text { reactive } \\
2 / 2\end{array}$ & $\begin{array}{l}\text { Fixed dilated } \\
5 / 5\end{array}$ & $\begin{array}{l}\text { Anisocoria } \\
4 / 3\end{array}$ & $\begin{array}{l}2 / 2 \\
\text { reactive }\end{array}$ & $2 / 2$ reactive \\
\hline Type of ICH & $\begin{array}{l}\text { Right convexity } \\
\text { SDH }\end{array}$ & $\begin{array}{l}\text { Right basal } \\
\text { ganglia ICB, } \\
\text { IVH }\end{array}$ & $\begin{array}{l}\text { Right } \\
\text { convexity } \\
\text { SDH }\end{array}$ & $\begin{array}{l}\text { Right } \\
\text { parietal } \\
\text { SDH }\end{array}$ & $\begin{array}{l}\text { SAH left } \\
\text { basal } \\
\text { cistern }\end{array}$ & $\begin{array}{l}\text { Left basal } \\
\text { ganglia ICB, } \\
\text { frontal ICB, } \\
\text { generalized } \\
\text { SAH }\end{array}$ & $\begin{array}{l}\text { Left } \\
\text { convexity } \\
\text { SDH }\end{array}$ & $\begin{array}{l}\text { Tentorium } \\
\text { cerebelli } \\
\text { SDH }\end{array}$ & $\begin{array}{l}\text { Tentorium } \\
\text { cerebelli SDH }\end{array}$ \\
\hline $\begin{array}{l}\text { Volume/max } \\
\text { thickness }\end{array}$ & $3 \mathrm{~cm}$ thickness & $30 \mathrm{ml}$ & $\begin{array}{l}1 \mathrm{~cm} \\
\text { thickness }\end{array}$ & $\begin{array}{l}0.5 \mathrm{~cm} \\
\text { thickness }\end{array}$ & Minimal & $\begin{array}{l}\text { Basal ganglia } \\
70 \mathrm{ml} \text {, frontal } \\
\text { lobe } 24 \mathrm{ml}\end{array}$ & $\begin{array}{l}2 \mathrm{~cm} \\
\text { thickness }\end{array}$ & Minimal & Minimal \\
\hline Midline shift & $\begin{array}{l}20 \mathrm{~mm} \text { to the } \\
\text { left }\end{array}$ & $\begin{array}{l}8 \mathrm{~mm} \text { to the } \\
\text { left }\end{array}$ & $\begin{array}{l}10 \mathrm{~mm} \text { to } \\
\text { the left }\end{array}$ & None & None & $\begin{array}{l}20 \mathrm{~mm} \text { to } \\
\text { the right }\end{array}$ & $\begin{array}{l}10 \mathrm{~mm} \text { to } \\
\text { the right }\end{array}$ & None & None \\
\hline Basal cisterns & $\begin{array}{l}\text { Partially } \\
\text { effaced }\end{array}$ & Fully effaced & $\begin{array}{l}\text { Fully } \\
\text { effaced }\end{array}$ & Patent & Patent & Fully effaced & $\begin{array}{l}\text { Fully } \\
\text { effaced }\end{array}$ & Patent & Patent \\
\hline Surgery & $\begin{array}{l}\text { Decompressive } \\
\text { craniectomy }\end{array}$ & None & $\begin{array}{l}\text { Parietal } \\
\text { craniectomy }\end{array}$ & None & None & None & None & None & None \\
\hline Outcome GOS & 1 & 1 & 1 & 5 & 3 & 1 & 1 & 5 & 5 \\
\hline
\end{tabular}

DM: Diabetes mellitus, ICH: Intracranial hemorrhage, UGIB: Upper gastrointestinal bleeding, INR: International normalized ratio, APTT: Activated partial thromboplastin time, ALT: Alanine transaminase, GCS: Glasgow coma scale, SDH: Subdural hemorrhage, IVH: Intraventricular hemorrhage, ICB: Intracerebral bleeding, SAH: Subarachnoid hemorrhage, GOS: Glasgow outcome scale, HPT: Hypertension, NS1: Type 1 nonstructural protein 


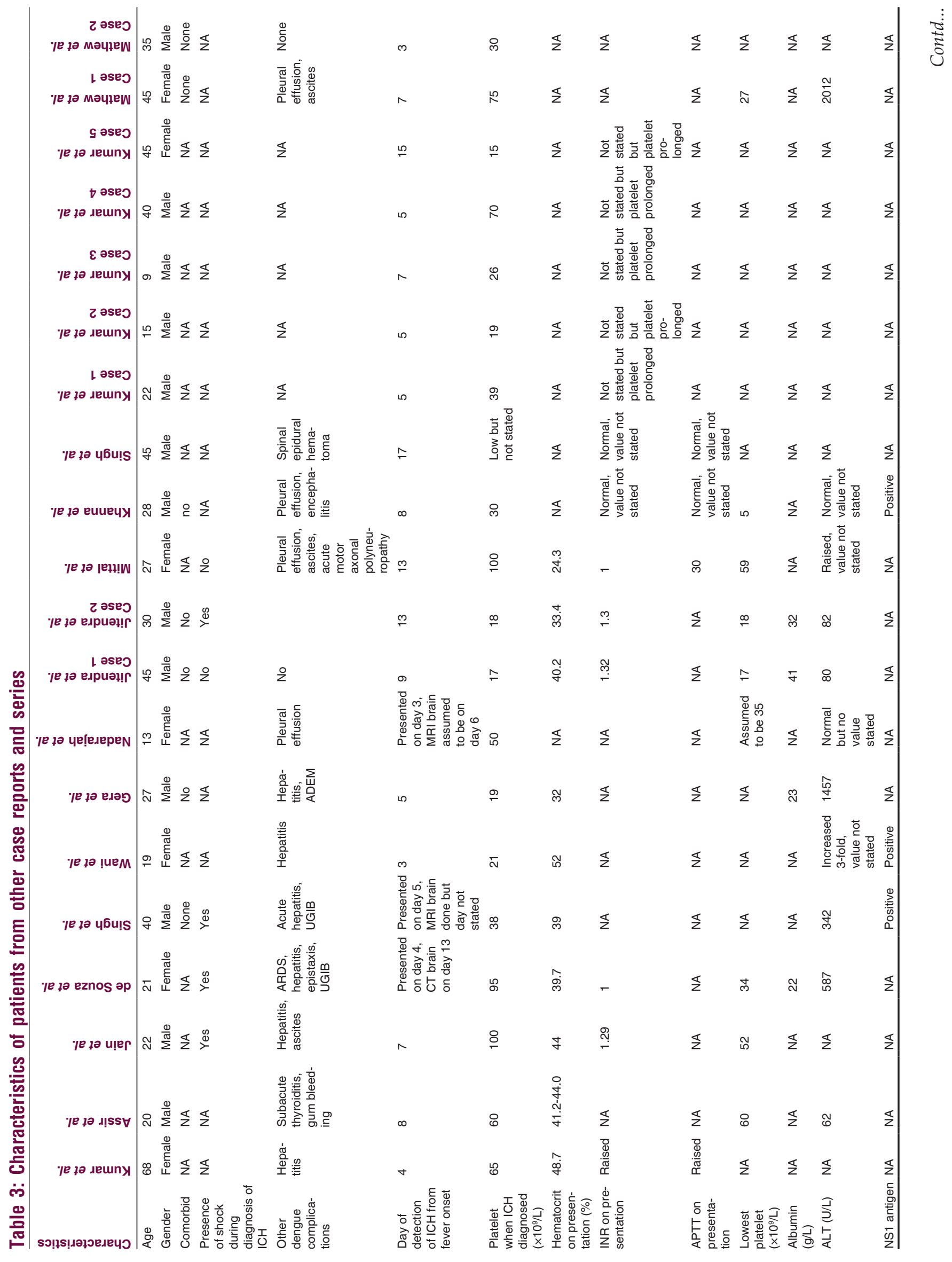




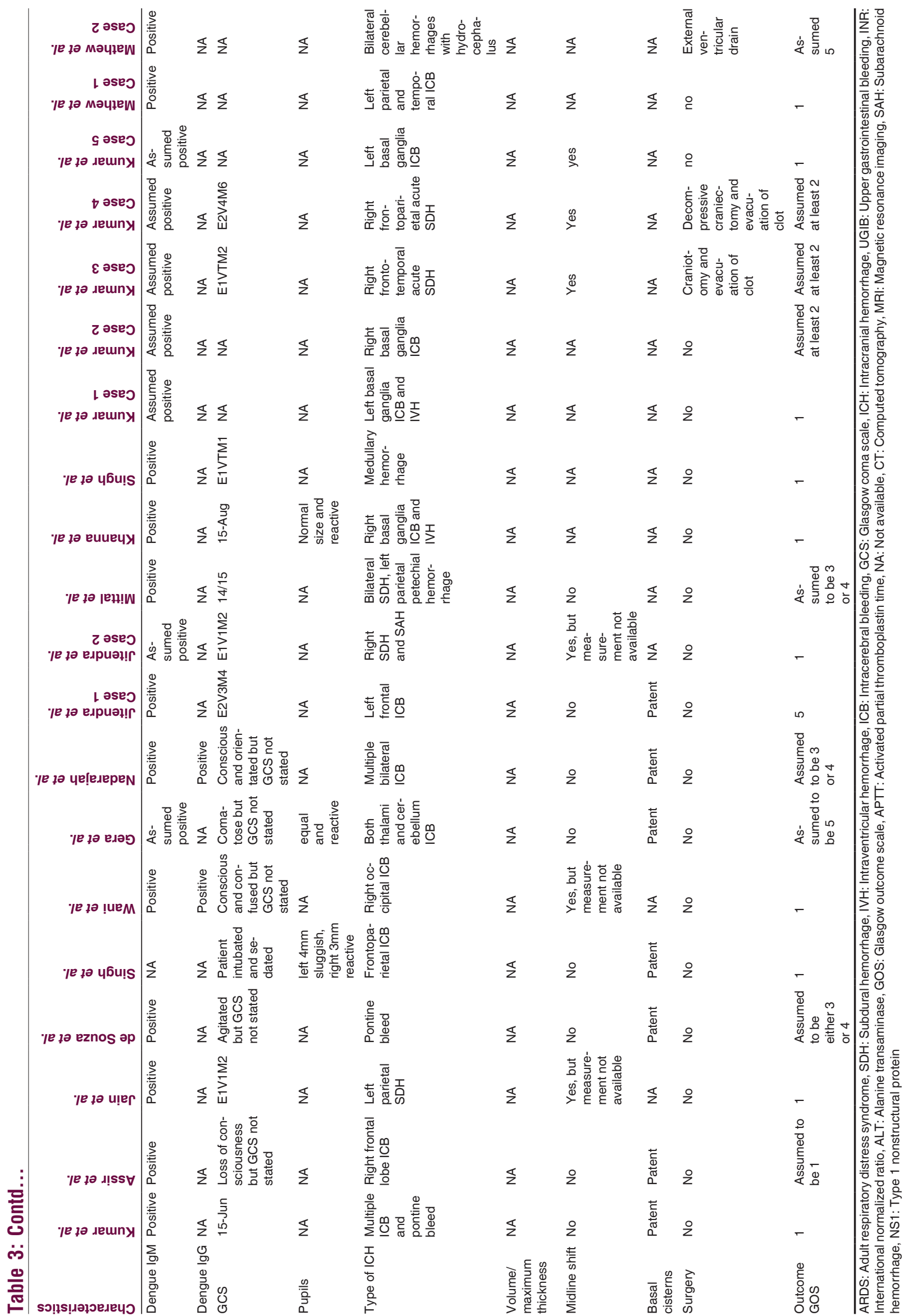




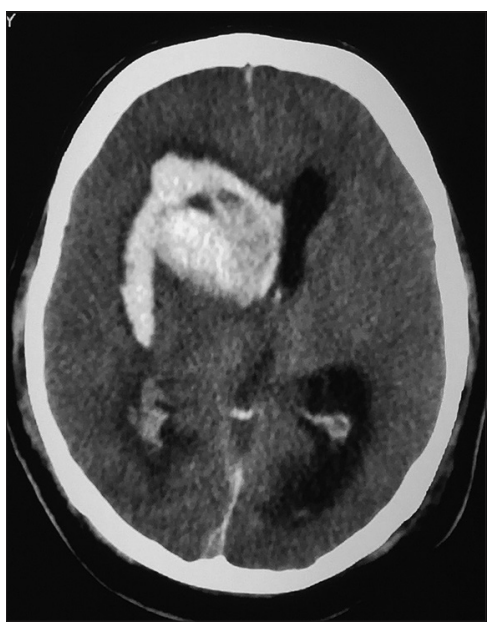

Figure 1: Computed tomography of the brain of patient B

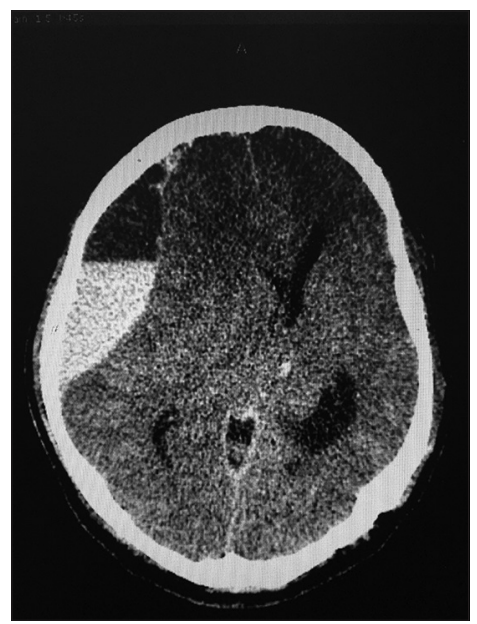

Figure 3: Computed tomography of the brain of patient $A$

with antibody detection. Initial suspicion of dengue fever usually rests upon the finding of leukopenia and thrombocytopenia from a full blood count. ${ }^{[28]}$ The most common tests used routinely are dengue IgM, IgG, and NS1, but only NS1 seems useful in making an early and accurate diagnosis. Each of these tests has its own disadvantages and cannot be used in isolation for every case. In primary infection, IgM antibodies are detectable in $50 \%$ of patients by days $3-5$, increasing to $80 \%$ by day $5,99 \%$ by day 10 , and peak about 2 weeks of illness before declining to undetectable levels over 2-3 months. $\mathrm{IgG}$ antibodies are generally detectable at low titers at the end of the $1^{\text {st }}$ week of illness and increasing slowly thereafter. During a secondary dengue infection, IgGs are the main antibodies and are detectable at high levels even in the acute phase. Early convalescent stage, IgM levels are significantly lower in secondary infections than in primary ones and may be undetectable. ${ }^{[6,29]}$

In secondary dengue infections, IgM was only detected in $78 \%$ of patients after day 7 in one study. ${ }^{[28]}$ If dengue

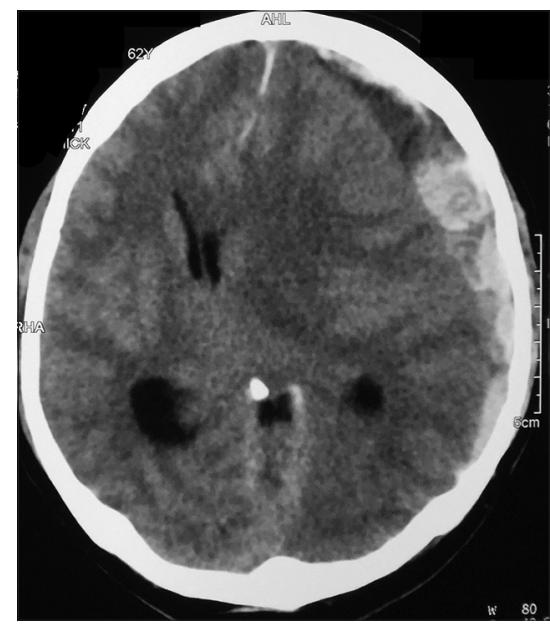

Figure 2: Computed tomography of the brain of patient $G$

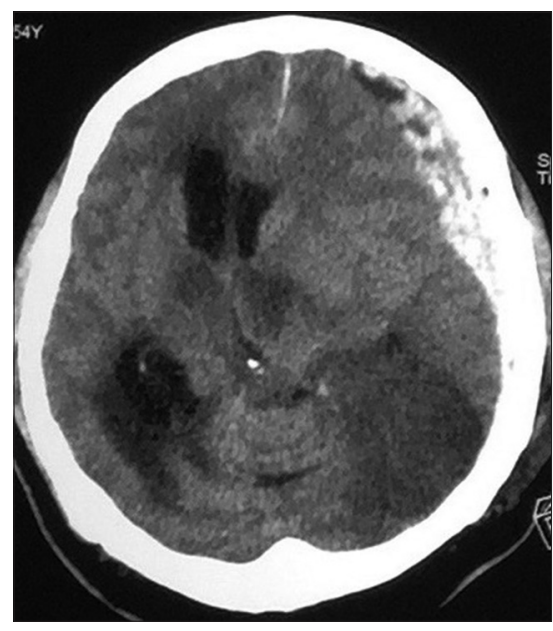

Figure 4: Computed tomography of the brain of patient $C$

IgM was the only test performed, it is reported that $28 \%$ of secondary dengue infections would be missed. ${ }^{[30]}$ This drawback limits the usefulness of IgM detection for diagnosing dengue infection in the acute phase of the illness when most patients present with complications such as ICH. NS1 antigen detection rate is significantly better in the acute phase of the disease. Unfortunately, it is found that its usefulness declines on day $4-5$ of illness but there are studies which show that NS1 antigen may be still be detected until the $14^{\text {th }}$ day of illness. ${ }^{[31-33]}$

A primary dengue infection invokes the immune system to protect the patient from a secondary infection from the same serotype. However, a phenomenon known as antibody-dependent enhancement of dengue virus infection may actually cause a more severe form of dengue infection. It is well accepted that patients with secondary dengue infections have a higher risk of developing more severe forms of dengue infection. ${ }^{[34]}$ Multiple methods such as using the IgM/IgG antibody ratios have thus been created to distinguish primary 
from secondary infections more accurately during the acute phase..$^{[6,35,36]}$

In our series, detection of IgG early in the course of the disease with a positive NS1 antigen test and negative IgM would most likely mean that the patient has a secondary infection. It is unfortunate that we do not have the titers of IgM and IgG to confirm this observation. In this series, all the patients had a positive NS1 test except for one, which could be due to sampling time after day 5 of illness. It is highly likely that the three patients with positive IgG had secondary dengue infection and thus were predisposed to have a more severe ICH. Even though sound clinical judgment would still be the best guidance for now, patients with a suspected secondary dengue infection should be monitored more closely and thresholds for diagnostic CT of the brains lowered when suspicion of ICH is present.

\section{Should neurosurgical intervention be considered?}

Whether surgery or optimal medical management should be the treatment of choice remains as the age-old question of all ICH. Dengue infections causing ICH are inherently harder to manage in that the causative factors such as vasculopathy and platelet dysfunction are usually still present and irreversible while surgery is undertaken. Some measures of correcting platelet deficits and coagulation derangements with massive transfusions may be carried out but risks delay of surgery. When the availability of neurosurgical centers is limited and transportation of a critically ill patient entails long-distance hazardous travel, the question of cost to benefit ratio becomes an issue. Considering the fact that the number of reported patients suffering ICH due to dengue infection is low, it is too early to advocate if these patients should be treated like any other spontaneous $\mathrm{ICH}$. The latest guidelines from the American Stroke Association recommends that supratentorial hematoma evacuation in deteriorating patients might be a life-saving surgery and that decompressive craniectomy may reduce mortality when there are large hematomas with significant midline shift or elevated intracranial pressure refractory to medical management. ${ }^{[37]}$ Some authors have illustrated that surgical treatment may be of benefit compared to medical management, but it is too premature to conclude with these limited data. ${ }^{[26,27]}$ The other question that needs to be answered is the timing of surgery. The debate remains on whether surgery should be done for these patients immediately with only platelet cover despite the low platelet levels or should adequate platelet levels as recommended by the guidelines be achieved first. The American Stroke Association advocates that early hematoma evacuation compared to hematoma evacuation when patient deteriorates does not show a clear benefit at the moment. ${ }^{[37]}$ There is conflicting evidence from the available studies such as the STICH II trial that showed no statistical significance in outcome between early surgery compared with initial medical management with delayed surgery if the patient deteriorates and the meta-analysis by another group which showed an improved outcome if surgery was performed within $8 \mathrm{~h}$ of hemorrhage. ${ }^{[38,39]}$ It would be difficult to determine if these recommendations could apply to ICH in patients with dengue infection.

\section{Recommendation for platelet and fresh frozen plasma transfusion}

Since thrombocytopenia and coagulopathy are usually severe in patients with dengue-related $\mathrm{ICH}$, neurosurgeons and physicians alike would have difficulty in determining the target levels and amount of blood product transfusion before surgery is undertaken. When ICH is present in patients with dengue infection, there is no study as to whether the large amounts of platelets and FFP given would change the outcome. As bleeding in dengue fever is multifactorial and still poorly understood, contributing factors such as vasculopathy and platelet dysfunction may be a cause of the hemorrhage, and the efforts for correcting the deficits may prove to be a waste of precious blood product resources and prolong the time from diagnosis to surgery. Moreover, it is shown that duration of survival of transfused platelets ranges from only a few hours to a day in cases with shock and that would mean that great amounts of blood products would be needed to keep the levels up.$^{[40]}$ A recent randomized control trial on platelet transfusion in dengue fever showed that $53.6 \%$ of their patients did not respond to platelet transfusion and these patients were those with a lower baseline platelet count. ${ }^{[41]}$ Unfortunately, current guidelines for platelet transfusion thresholds in thrombocytopenic surgical patients are mainly based on expert opinion and clinical experience. The current recommendation for platelet levels for neurosurgical procedures is $100 \times 10^{9} / \mathrm{L} \cdot{ }^{[22,43]} \mathrm{In}$ dengue patients, it is difficult to keep the perioperative platelet levels as recommended and it is shown that a perioperative platelet count below $100 \times 10^{9} / \mathrm{L}$ in patients who failed to respond to platelet transfusions had a higher risk of postoperative intracranial hematoma formation. ${ }^{[4]}$ Recommendations for optimum INR before neurosurgical procedures range from 1.5 to $1.7 .{ }^{[45,46]}$

There are two schools of thought for platelet transfusion. One group suggests prophylactic transfusion of platelets when levels are under a certain threshold, of which the threshold values still vary at the moment. The other group prefers transfusion only when significant hemorrhage occurs. One study showed that a platelet 
count of $<50 \times 10^{9} / \mathrm{L}$ and hematocrit of more than 50 are associated with bleeding manifestations. ${ }^{[47]}$ One more study of 225 dengue patients suggested that bleeding occurred more often in patients with platelet counts below $20 \times 10^{9} / \mathrm{L}$ and recommended prophylactic transfusion of platelets. ${ }^{[48]}$ Other authors promote transfusion if platelet levels are below $10 \times 10^{9} / \mathrm{L}{ }^{[49,50]}$

In contrast, there was no correlation between bleeding tendencies and platelet counts in dengue patients in other studies. ${ }^{[51,52]}$ For dengue fever without bleeding, one study showed that prophylactic transfusions of platelet are not recommended as it does not change or reduce the bleeding outcome in patients with dengue hemorrhagic fever and may increase risk of pulmonary edema. ${ }^{[53]}$ Platelet transfusion in adult patients with dengue in the absence of bleeding when the platelet count was $<20 \times 10^{9} / \mathrm{L}$ did not reduce bleeding or hasten platelet recovery, but there was potential harm by hampering recovery of platelet count to $>50 \times 10^{9} / \mathrm{L}$ and prolonging of hospitalization. ${ }^{[54,55]}$ In a retrospective analysis of 256 dengue-infected patients without prior bleeding and platelet counts $<20 \times 10^{9} / \mathrm{L}, 188$ were given platelet transfusion; it was found that subsequent bleeding, platelet increment, and platelet recovery were similar between the two groups. ${ }^{[56]}$ A review article in 2011 strongly concluded that prophylactic platelet transfusion is associated with hazards and wastage, which is not justified by any potential hematological benefit and therefore, should not be adopted as a routine clinical practice. ${ }^{[57]}$ There was no clear mention of ICH in these studies.

Then again, a salient point that must be considered in patients with ICH is the significant morbidity that could be worse than mortality itself at times. The question arises as to whether prophylactic transfusion should be given to patients with very low platelet levels just to avoid devastating consequences of ICH even though it is a rare event. The range of lowest recorded platelet levels in our series was $2-76 \times 10^{9} / \mathrm{L}$ and five of the patients had coagulopathy. Our series shows that severe ICH may still occur even with a platelet count of 66 (Patient F) and a platelet count of 3 does not cause a more severe $\mathrm{ICH}$ (Patient D). It has long been established that there is abnormal hemostasis in patients with dengue fever with platelet dysfunction, coagulopathy, vasculopathy, and immune- or virus-related destruction of platelets. ${ }^{[58,59]} \mathrm{It}$ may be possible that our approach of determining the absolute platelet counts and INR might not be entirely enough as we might be missing out on the actual ability of platelet function and coagulation in vivo. There are laboratory techniques to assess platelet function and blood coagulation, namely, thromboelastography, thromboelastometry, and platelet aggregometry. Although not widely available yet in developing countries, these tests might prove useful in determining a subset of patients that may benefit from prophylactic transfusions to prevent life-threatening hemorrhages. To our knowledge, there has been no trial in the use of thromboelastography, thromboelastometry, or platelet aggregometry in predicting bleeding tendencies in patients with dengue fever.

\section{When should a computed tomography scan of the brain be done?}

Headache, fever, and vomiting are the most common manifestations of dengue infection. It is important to consider that these symptoms may also be the first symptom of an ongoing ICH. Unequivocal symptoms such as seizures, weakness, numbness, altered consciousness, and seizures would warrant CT of the brains, but these presentations may only be present when the ICH has expanded beyond treatment. Multiple methods of noninvasive monitoring and detection of raised intracranial pressure have been developed, but most are expensive and require much training. ${ }^{[60]} \mathrm{In}$ view of this, a simple noninvasive method to detect increased intracranial pressure is needed. In the setting where dengue infections are highest in developing nations and CT of the brains are not widely available, we can only recommend that fundoscopy to detect papilledema should be a routine assessment for dengue-infected patients with suspected ICH. It is sad however that none of our patients had fundoscopy performed on them.

Can risk factors for predicting severe dengue be used to predict the occurrence of intracranial hemorrhage?

It would seem from our series that prevention of $\mathrm{ICH}$ in patients with dengue should be the main aim as all patients who had a severe bleed warranting surgery deteriorated very quickly and both surgical and medical managements failed to stop the inevitable. If specific risk factors could be identified, perhaps, prophylactic transfusion and closer monitoring could bring about earlier detection or prevent ICH altogether. In terms of risk of bleeding, a study done in Malaysia found that prolonged duration of shock and low-normal hematocrit at the time of shock suggesting blood loss in addition to capillary leakage were the strongest predictors of hemorrhage. ${ }^{[53]}$ Only Patient $G$ in our series who had upper gastrointestinal bleeding had a low hematocrit and shock. It is possible that patients with only ICH as the only bleeding tendency would not show a drop in hematocrit associated with shock as the volume of intracranial blood loss alone would not be sufficient enough to reduce intravascular volume. Other studies found that there was significant association between bleeding tendencies and 
older patients, secondary dengue infection, high baseline hematocrit levels, low platelet levels, prolonged APTT, female gender, vomiting, high absolute lymphocyte count, and high aspartate aminotransferase level. ${ }^{[61,62]}$ Even though these may be generalized to include $\mathrm{ICH}$, it would be ideal if independent risk factors for ICH could be determined. Although not specific to ICH, Sahu et al. outlined the possible predictors for the central nervous system involvement that includes higher mean body temperature, elevated hematocrit, low platelet count, and liver dysfunction. ${ }^{[63]}$ Three of our patients with positive IgG had ICH requiring surgery and all of them died, whereas two patients with negative IgG did not have ICH requiring surgery and survived; thus, it is possible that secondary dengue infection is also associated with a tendency to develop severe ICH.

\section{Possible etiology of intracranial hemorrhage}

The mechanisms of which patients with dengue infection may be more prone to $\mathrm{ICH}$ is complex and are postulated to be caused by coagulopathy, platelet dysfunction, thrombocytopenia, and vasculopathy. ${ }^{[8,11]}$ To date, there is no proven explanation for ICH occurring in only a rare minority of patients with severe dengue. The blood-brain barrier and blood-cerebrospinal fluid (CSF) barrier have been shown to breakdown during dengue virus infection. ${ }^{[64,65]}$ Dengue IgM, IgG, and NS1 Ag were also detected in CSF of patients with dengue. ${ }^{[6]}$ It is plausible that ICH follows the same general mechanisms as bleeding elsewhere in the body and focal cerebral vasculopathy is worsened by the presence of $\operatorname{IgG}$ and NS1 Ag immunopathological-related mechanisms. In general, immunopathological events involving T cells, cytokines such as tumor necrosis factor-alpha (TNF- $\alpha$ ), and cross-reactive antibody that enhances dengue virus replication leading to vasculopathy are still incompletely understood. ${ }^{[6,67]}$ Thrombocytopenia may be caused by disseminated intravascular coagulation, bone marrow suppression, increased apoptosis, and destruction by the complement system. ${ }^{[68]}$ There are many newly suggested detailed mechanisms for bleeding in dengue. Interestingly, NS1 antigens are found to induce production of plasminogen cross-reactive antibodies and thus enhance plasminogen activation leading to increased plasmin and promoting fibrinolysis. ${ }^{[69]}$ Platelet dysfunction and destruction have been attributed to the dengue virus and early studies reveal that dengue virus viremia seems associated with the megakaryocytic lineage and replication in platelets. ${ }^{[70,71]}$ Much have been learned and platelets have been increasingly considered to play a key role in inflammation through inflammasome synthesis of interleukin- 1 beta (IL-1 $\beta$ ) which is a cytokine closely associated with endothelial dysfunction and coagulation disorders. Platelets activation by dengue virus through lectin receptor dendritic cell-specific ICAM-3-grabbing nonintegrin resulting in production of IL-1 $\beta$ has been shown ${ }^{[72,73]}$ Using mouse models, Chen et al. observed that high viral titer, macrophage infiltration, and TNF- $\alpha$ are three important events that lead to hemorrhage. ${ }^{[7]}$ Chuang et al. found that dengue virus infection induced macrophage migration inhibitory factor (MIF) production may contribute to vascular hyperpermeability and hemostatic abnormality and thus blocking of MIF may be an answer for prevention of dengue hemorrhage. ${ }^{[75]}$

\section{Conclusion}

The rapid spread of dengue virus infection is alarming and needs global attention. This article highlights the deadly effect of dengue hemorrhagic encephalopathy and the limited weapons and knowledge we have against it. More research is needed in this field to determine possible predictors of $\mathrm{ICH}$ such as dengue IgG in dengue infection.

\section{Acknowledgment}

We would like to thank the Pathology Department of Hospital Pulau Pinang for providing us information on the laboratory tests for diagnosis of dengue fever. We would also like to thank the Director General of Health Malaysia, Datuk Dr. Noor Hisham Abdullah, for allowing us to publish this article.

\section{Financial support and sponsorship \\ Nil.}

\section{Conflicts of interest}

There are no conflicts of interest.

\section{References}

1. Ministry of Health Malaysia. Clinical practice guidelines: Management of dengue infection in adults. $2^{\text {nd }}$ Revised Edition. Kuala Lumpur: Academy of Medicine Malaysia; 2010.

2. Dengue and Severe Dengue: Fact Sheet No. 117. Geneva: World Health Organization; 2015. Available from: http://www.who.int/mediacentre/ factsheets/fs117/en/. [Last cited on 2015 Nov 10].

3. Official Portal for Ministry of Health Malaysia. Malaysia: Ministry of Health Malaysia; c2013-2016. Available from: http://www.moh.gov.my/ index.php/database_stores/store_view/17. [Last updated on 2015 Jul 01; Last cited on 2016 Apr 01].

4. Thisyakorn U, Thisyakorn C. Dengue vaccines. Southeast Asian J Trop Med Public Health 2015;46 Suppl 1:138-45.

5. World Health Organization. Dengue Hemorrhagic Fever: Diagnosis, Treatment, Prevention, and Control. $2^{\text {nd }}$ ed. Geneva: World Health Organization; 1997.

6. World Health Organization and Special Programme for Research and Training in Tropical Diseases. Dengue: Guidelines for Diagnosis, Treatment, Prevention, and Control. New Edition. Geneva: World Health Organization; 2009. 
7. World Health Organization Regional Office for South East Asia. Comprehensive Guidelines for Prevention and Control of Dengue and Dengue Hemorrhagic Fever. Revised and Expanded Edition. New Delhi: World Health Organization South East Asia Regional Office; 2011.

8. Cam BV, Fonsmark L, Hue NB, Phuong NT, Poulsen A, Heegaard ED. Prospective case-control study of encephalopathy in children with dengue hemorrhagic fever. Am J Trop Med Hyg 2001;65:848-51.

9. Hendarto SK, Hadinegoro SR. Dengue encephalopathy. Acta Paediatr Jpn 1992;34:350-7.

10. Solomon T, Dung NM, Vaughn DW, Kneen R, Thao LT, Raengsakulrach B, et al. Neurological manifestations of dengue infection. Lancet 2000;355:1053-9.

11. Puccioni-Sohler M, Soares CN, Papaiz-Alvarenga R, Castro MJ, Faria LC, Peralta JM. Neurologic dengue manifestations associated with intrathecal specific immune response. Neurology 2009;73:1413-7.

12. Jennett B, Snoek J, Bond MR, Brooks N. Disability after severe head injury: Observations on the use of the Glasgow Outcome Scale. J Neurol Neurosurg Psychiatry 1981;44:285-93.

13. Kwak R, Kadoya S, Suzuki T. Factors affecting the prognosis in thalamic hemorrhage. Stroke 1983;14:493-500.

14. Broderick JP, Brott TG, Tomsick T, Barsan W, Spilker J. Ultra-early evaluation of intracerebral hemorrhage. J Neurosurg 1990;72:195-9.

15. Kothari RU, Brott T, Broderick JP, Barsan WG, Sauerbeck LR, Zuccarello $\mathrm{M}$, et al. The ABCs of measuring intracerebral hemorrhage volumes. Stroke 1996;27:1304-5.

16. Kumar J, Kumar A, Gupta S, Jain D. Neurological picture. Dengue haemorrhagic fever: An unusual cause of intracranial haemorrhage. J Neurol Neurosurg Psychiatry 2007;78:253.

17. Assir MZ, Jawa A, Ahmed HI. Expanded dengue syndrome: Subacute thyroiditis and intracerebral hemorrhage. BMC Infect Dis 2012;12:240.

18. Jain N, Gutch M, Kumar V, Naik AK. A fatal combo of dengue shock syndrome with acute subdural hematoma. Neurol India 2012;60:105-6.

19. de Souza LJ, Martins AL, Paravidini PC, Nogueira RM, Gicovate Neto C, Bastos DA, et al. Hemorrhagic encephalopathy in dengue shock syndrome: A case report. Braz J Infect Dis 2005;9:257-61.

20. Wani AM, Mejally MA, Hussain WM, Maimani WA, Hanif S, Khoujah AM, et al. Skin rash, headache and abnormal behaviour: Unusual presentation of intracranial haemorrhage in dengue fever. BMJ Case Rep 2010;2010. pii: Bcr06.2009.1949.

21. Gera C, George U. Acute disseminating encephalomyelitis with hemorrhage following dengue. Neurol India 2010;58:595-6.

22. Singh J, Dinkar A, Atam V, Misra R, Kumar S, Gupta K, et al. Intracranial hemorrhage in dengue fever: A case series. J Med Sci Clin Res 2015;3:4447-52. https://www.researchgate.net/publication/279202776_Intracranial_ Hemorrhage_in_Dengue_Fever_A_Case_Series. [Last accessed on 2016 May 14].

23. Mittal M, Jain N. Subdural haematoma and axonal polyneuropathy complicating dengue fever. BMJ Case Rep 2011;2011. pii: Bcr1220103672.

24. Khanna A, Atam V, Gupta A. A case of dengue encephalitis with intracerebral hemorrhage. J Glob Infect Dis 2011;3:206-7.

25. Singh M, Garg K, Bisht A, Sharma BS, Singh PK, Pandia M, et al. Spinal epidural hematoma with myelitis and brainstem hemorrhage: An unusual complication of dengue fever. Neurol India 2013;61:541-3.

26. Kumar R, Prakash O, Sharma BS. Intracranial hemorrhage in dengue fever: Management and outcome: A series of 5 cases and review of literature. Surg Neurol 2009;72:429-33.

27. Mathew S, Pandian JD. Stroke in patients with dengue. J Stroke Cerebrovasc Dis 2010;19:253-6.

28. Schilling S, Ludolfs D, Van An L, Schmitz H. Laboratory diagnosis of primary and secondary dengue infection. J Clin Virol 2004;31:179-84.

29. Peeling RW, Artsob H, Pelegrino JL, Buchy P, Cardosa MJ, Devi S, et al. Evaluation of diagnostic tests: Dengue. Nat Rev Microbiol 2010;8 12 Suppl: S30-8.

30. Gubler DJ. Dengue and dengue hemorrhagic fever. Clin Microbiol Rev 1998;11:480-96.

31. Alcon S, Talarmin A, Debruyne M, Falconar A, Deubel V, Flamand M. Enzyme-linked immunosorbent assay specific to Dengue virus type 1 nonstructural protein NS1 reveals circulation of the antigen in the blood during the acute phase of disease in patients experiencing primary or secondary infections. J Clin Microbiol 2002;40:376-81.

32. Kumarasamy V, Wahab AH, Chua SK, Hassan Z, Chem YK, Mohamad M, et al. Evaluation of a commercial dengue NS1 antigen-capture ELISA for laboratory diagnosis of acute dengue virus infection. J Virol Methods 2007;140:75-9.

33. Wang SM, Sekaran SD. Evaluation of a commercial SD dengue virus NS1 antigen capture enzyme-linked immunosorbent assay kit for early diagnosis of dengue virus infection. J Clin Microbiol 2010;48:2793-7.

34. Rothman AL, Ennis FA. Immunopathogenesis of Dengue hemorrhagic fever. Virology 1999;257:1-6.

35. Matheus S, Deparis X, Labeau B, Lelarge J, Morvan J, Dussart P. Discrimination between primary and secondary dengue virus infection by an immunoglobulin $\mathrm{G}$ avidity test using a single acute-phase serum sample. J Clin Microbiol 2005;43:2793-7.

36. Cordeiro MT, Braga-Neto U, Nogueira RM, Marques ET Jr. Reliable classifier to differentiate primary and secondary acute dengue infection based on IgG ELISA. PLoS One 2009;4:e4945.

37. Hemphill JC $3^{\text {rd }}$, Greenberg SM, Anderson CS, Becker K, Bendok BR, Cushman M, et al. Guidelines for the management of spontaneous intracerebral hemorrhage: A guideline for healthcare professionals from the American Heart Association/American Stroke Association. Stroke 2015;46:2032-60.

38. Mendelow AD, Gregson BA, Rowan EN, Murray GD, Gholkar A, Mitchell PM; STICH II Investigators. Early surgery versus initial conservative treatment in patients with spontaneous supratentorial lobar intracerebral haematomas (STICH II): A randomised trial. Lancet 2013;382:397-408.

39. Gregson BA, Broderick JP, Auer LM, Batjer H, Chen XC, Juvela S, et al. Individual patient data subgroup meta-analysis of surgery for spontaneous supratentorial intracerebral hemorrhage. Stroke 2012;43:1496-504.

40. Isarangkura $\mathrm{P}$, Tuchinda $\mathrm{S}$. The behavior of transfused platelets in dengue hemorrhagic fever. Southeast Asian J Trop Med Public Health 1993;24 Suppl 1:222-4.

41. Khan Assir MZ, Kamran U, Ahmad HI, Bashir S, Mansoor H, Anees SB, et al. Effectiveness of platelet transfusion in dengue fever: A randomized controlled trial. Transfus Med Hemother 2013;40:362-8.

42. Cooper E, Bracey AW, Horvath AE, Shanberge JN, Simon TL, Yawn DH. Practice parameter for the use of fresh-frozen plasma, cryoprecipitate, and platelets. JAMA 1994;271:777-81.

43. Slichter SJ. Evidence-based platelet transfusion guidelines. Hematology Am Soc Hematol Educ Program 2007;1:172-8.

44. Chan KH, Mann KS, Chan TK. The significance of thrombocytopenia in the development of postoperative intracranial hematoma. J Neurosurg 1989;71:38-41.

45. Matevosyan K, Madden C, Barnett SL, Beshay JE, Rutherford C, Sarode R. Coagulation factor levels in neurosurgical patients with mild prolongation of prothrombin time: Effect on plasma transfusion therapy. J Neurosurg 2011;114:3-7.

46. Szczepiorkowski ZM, Dunbar NM. Transfusion guidelines: When to transfuse. Hematology Am Soc Hematol Educ Program 2013;2013:638-44.

47. Malavige GN, Velathanthiri VG, Wijewickrama ES, Fernando S, Jayaratne SD, Aaskov J, et al. Patterns of disease among adults hospitalized with dengue infections. QJM 2006;99:299-305.

48. Makroo RN, Raina V, Kumar P, Kanth RK. Role of platelet transfusion in the management of dengue patients in a tertiary care hospital. Asian J Transfus Sci 2007;1:4-7.

49. Singhi S, Kissoon N, Bansal A. Dengue and dengue hemorrhagic fever: Management issues in an intensive care unit. J Pediatr (Rio J) 2007;83 2 Suppl: S22-35.

50. Dutta AK, Biswas A, Baruah K, Dhariwal AC. National guidelines for diagnosis and management of dengue fever/dengue haemorrhagic fever and dengue shock syndrome. J Indian Med Assoc 2011;109:30-5.

51. Chaudhary R, Khetan D, Sinha S, Sinha P, Sonker A, Pandey P, et al. Transfusion support to dengue patients in a hospital based blood transfusion service in North India. Transfus Apher Sci 2006;35:239-44.

52. Mourão MP, Lacerda MV, Macedo VO, Santos JB. Thrombocytopenia in patients with dengue virus infection in the Brazilian Amazon. Platelets 2007;18:605-12.

53. Lum LC, Abdel-Latif Mel-A, Goh AY, Chan PW, Lam SK. Preventive 
transfusion in dengue shock syndrome-is it necessary? J Pediatr 2003;143:682-4.

54. Lee TH, Wong JG, Leo YS, Thein TL, Ng EL, Lee LK, et al. Potential harm of prophylactic platelet transfusion in adult dengue patients. PLoS Negl Trop Dis 2016;10:e004576.

55. Prashantha B, Varun S, Sharat D, Murali MBV, Ranganatha R, Shivaprasad, et al. Prophyactic platelet transfusion in stable dengue fever patients: Is it really necessary? Indian J Hematol Blood Transfus 2014;30:126-9.

56. Lye DC, Lee VJ, Sun Y, Leo YS. Lack of efficacy of prophylactic platelet transfusion for severe thrombocytopenia in adults with acute uncomplicated dengue infection. Clin Infect Dis 2009;48:1262-5.

57. Kurukularatne C, Dimatatac F, Teo DL, Lye DC, Leo YS. When less is more: Can we abandon prophylactic platelet transfusion in dengue fever? Ann Acad Med Singapore 2011;40:539-45.

58. Srichaikul T, Nimmannitya S, Sripaisarn T, Kamolsilpa M, Pulgate C. Platelet function during the acute phase of dengue hemorrhagic fever. Southeast Asian J Trop Med Public Health 1989;20:19-25.

59. Hathirat P, Isarangkura P, Srichaikul T, Suvatte V, Mitrakul C. Abnormal hemostasis in dengue hemorrhagic fever. Southeast Asian J Trop Med Public Health 1993;24 Suppl 1:80-5.

60. Raboel PH, Bartek J Jr., Andresen M, Bellander BM, Romner B. Intracranial pressure monitoring: Invasive versus non-invasive methods-a review. Crit Care Res Pract 2012;2012:950393.

61. Tee HP, How SH, Jamalludin AR, Safhan MN, Sapian MM, Kuan YC, et al. Risk factors associated with development of dengue haemorrhagic fever or dengue shock syndrome in adults in Hospital Tengku Ampuan Afzan Kuantan. Med J Malaysia 2009;64:316-20.

62. Chamnanchanunt S, Kanagaraj D, Thanachartwet V, Desakorn V, Rojnuckarin P. Early predictors of clinically significant bleeding in adults with dengue infection. Southeast Asian J Trop Med Public Health 2012;43:890-9.

63. Sahu R, Verma R, Jain A, Garg RK, Singh MK, Malhotra HS, et al. Neurologic complications in dengue virus infection: A prospective cohort study. Neurology 2014;83:1601-9.

64. Chaturvedi UC, Dhawan R, Khanna M, Mathur A. Breakdown of the blood-brain barrier during dengue virus infection of mice. J Gen Virol 1991;72 (Pt 4):859-66.

65. Puccioni-Sohler M, Rosadas C, Cabral-Castro MJ. Neurological complications in dengue infection: A review for clinical practice. Arq Neuropsiquiatr 2013;71:667-71.

66. Fink J, Gu F, Vasudevan SG. Role of T cells, cytokines and antibody in dengue fever and dengue haemorrhagic fever. Rev Med Virol 2006;16:263-75.

67. Kurane I. Dengue hemorrhagic fever with special emphasis on immunopathogenesis. Comp Immunol Microbiol Infect Dis 2007;30:329-40

68. de Azeredo EL, Monteiro RQ, de-Oliveira Pinto LM. Thrombocytopenia in dengue: Interrelationship between virus and the imbalance between coagulation and fibrinolysis and inflammatory mediators. Mediators Inflamm 2015;2015:313842.

69. Chuang YC, Lin J, Lin YS, Wang S, Yeh TM. Dengue virus nonstructural protein 1-induced antibodies cross-react with human plasminogen and enhance its activation. J Immunol 2016;196:1218-26.

70. Noisakran S, Chokephaibulkit K, Songprakhon P, Onlamoon N, Hsiao HM, Villinger F, et al. A re-evaluation of the mechanisms leading to dengue hemorrhagic fever. Ann N Y Acad Sci 2009;1171:E24-35.

71. Rondina MT, Weyrich AS. Dengue virus pirates human platelets. Blood 2015;126:286-7.

72. Hottz ED, Monteiro AP, Bozza FA, Bozza PT. Inflammasome in platelets: Allying coagulation and inflammation in infectious and sterile diseases? Mediators Inflamm 2015;2015:435783.

73. Hottz ED, Lopes JF, Freitas C, Valls-de-Souza R, Oliveira MF, Bozza MT, et al. Platelets mediate increased endothelium permeability in dengue through NLRP3-inflammasome activation. Blood 2013;122:3405-14.

74. Chen HC, Hofman FM, Kung JT, Lin YD, Wu-Hsieh BA. Both virus and tumor necrosis factor alpha are critical for endothelium damage in a mouse model of dengue virus-induced hemorrhage. J Virol 2007;81:5518-26.

75. Chuang YC, Chen HR, Yeh TM. Pathogenic roles of macrophage migration inhibitory factor during dengue virus infection. Mediators Inflamm 2015;2015:547094. 